\title{
Can you cartwheel with an ostomy?
}

\author{
Karin Camposagrado discusses how healthcare professionals have helped her adjust to life with \\ an ileostomy
}

\author{
Karin Camposagrado
}

It might seem odd, but not being able to cartwheel after my surgery was one of my biggest concerns as I contemplated a total colectomy and an ileostomy. The answer from everyone I asked was "you can do anything with an ostomy that you did before you had one." This belief paved the way for me to confidently choose to have ostomy surgery. An ostomy diverts waste (stool or urine) from the body into an ostomy pouch. My ostomy diverts stool from my small intestine into my ostomy pouch. To me knowing that I could do anything that I could before the operation was the solution to a huge problem.

Once the surgery was complete, I began to worry about trying new foods, exercising and building my strength back up, getting diarrhoea and becoming dehydrated, pooping while changing my pouch, whether my clothes would ever be comfortable again. But more than anything I worried about leaks and how to handle them.

\section{Simple advice}

The nurses helped by encouraging me to look at my stoma. Even though I wasn't ready to do that and resisted, they were gently persistent and eventually I agreed to take a peek. It was a lot to take in, but I appreciated that they encouraged me to start by just looking and didn't ask me to do a full pouch change right away. Later that day my worst fears were realised, when my pouch leaked. The nurse recognised that I wasn't ready to change the pouch myself, but she still encouraged me to watch her at work.

It was my turn before I knew it. My home health nurse assured me she was there to guide me, answer my questions, and support me. During one of the changes I started pooping while my appliance was off. I started to panic and my legs began to shake. I wanted to cry as I looked to the nurse for guidance. She told me that it would stop, but to take a deep breath and wait a moment. I got through that change because of her quiet confidence in me along with her patience and acceptance. Just knowing that she would support me without judgment made me feel confident in doing the changes. In hindsight, her advice was simple. In the moment, it made everything click.

\section{Explaining to others}

I've since been to numerous doctor appointments, many of which have been with healthcare professionals who do not have much - if any-experience with ostomies. Although information about my ostomy is in my medical chart, I often still mention this in initial meetings to make sure that everyone is aware of it. For me, having healthcare professionals who are curious about my ostomy is comforting. I'm more at ease when they adapt their bowel related questions to what it would be like for an ostomate. For example, instead of asking "how many times do you poop per day," ask "have you noticed any changes in your output recently?" This helps me know that you recognise that what is normal for me will be different from that of your other patients. I also feel more relaxed with healthcare professionals who recognise that I've taken the time to educate myself about my ostomy by listening to my concerns and being willing to consider my perspective as the patient. This makes me feel much more confident to work with them to find solutions to any problems.

People might think that having an ostomy will affect their life negatively. But for me, living with an ostomy has enhanced my life both physically, socially, and emotionally. This isn't to say that it's not a challenge sometimes, but I'm grateful for the life it's allowing me to live.

What you need to know

Encourage your patients to challenge themselves, whether it is taking a peek at what you are doing or having them be hands-on, doing it themselves

- Sometimes just knowing you are there if patients need help can make them feel more comfortable self managing

- For patients with an ostomy, treatment decisions will depend on their symptoms and the impact these have on their daily life. Knowing what is normal for them will help with decision making 


\section{Education into practice}

- What information and expertise can you draw on when helping patients weigh up the pros and cons of having ostomy surgery?

- In the first few days after ostomy surgery how could you better support someone to take in their appearance and the changes to their body?

- See one, do one, teach one is a common mantra for mastering clinical skills and procedures. How do you support patients to learn the skills needed to master essential aspects of self care or management after a procedure such as an ostomy?

- When consulting with people with an ostomy, how and when might you bring it up? To what extent do you use adapted language such as "output"?
As a part of my healing process, I started the website and blog www.newbieostomy. com. It is filled with information about ostomies and is curated with the intention to spread positive ostomy awareness and education. Another great resource for ostomy information and to find local support groups in the United States is www. ostomy.org

Competing interests: $\mathrm{KC}$ is a consultant for Safe $\mathrm{n}$ Simple and 11 Health.

Provenance and peer review: Commissioned, based on an idea from the author; not externally peer reviewed.

Published by the BMJ Publishing Group Limited. For permission to use (where not already granted under a licence) please go to http://group.bmj.com/group/rights-licensing/ permissions 